\title{
Sedative and antinociceptive effects of romifidine and xylazine in Thoroughbred mares
}

\author{
[Efeito sedativo e antinociceptivo da romifidina e xilazina em éguas Puro Sangue Inglês] \\ F.G. Christovão, G. Zamur, M.I. Mataqueiro, A. Queiroz-Neto* \\ Faculdade de Ciências Agrárias e Veterinárias - UNESP \\ Via de Acesso Prof. Paulo D. Castellane, s/n \\ 14884-900 - Jaboticabal, SP
}

\begin{abstract}
The sedative and antinociceptive effects of romifidine $(0.1 \mathrm{mg} / \mathrm{kg})$ and of xylazine $(1.0 \mathrm{mg} / \mathrm{kg})$ on Thoroughbred mares were studied. Sedation was evaluated by quantifying spontaneous locomotor activity (SLA) and head height (HH) in animals placed in automated individual behaviour stalls. Antinociception was determined utilizing a heat irradiation lamp recording the latency time for the hoof withdrawal reflex (HWRL) and the latency time for the skin twitch reflex (STRL) in a randomised block design with 10 replicates. Comparison of the sedative effects of romifidine and of xylazine on SLA showed a faster effect for xylazine. Regarding the sedative effect of the substances based on $\mathrm{HH}$, romifidine caused a longer-lasting effect. Romifidine caused an increase in HWRL and STRL, and xylazine, an agent known for its analgesic effect, did not have an antinociceptive effect based on STRL result. The antinociceptive effect of romifidine was more pronounced than the xylazine effect.
\end{abstract}

Keywords: horse, romifidine, xylazine, antinociception, sedation

\section{RESUMO}

Compararam-se os efeitos sedativos e antinociceptivos da romifidina $(0,1 \mathrm{mg} / \mathrm{kg})$ e da xilazina $(1,0 \mathrm{mg} / \mathrm{kg})$ em éguas da raça Puro Sangue Inglês. A sedação foi quantificada por meio da atividade locomotora espontânea (ALE) e altura da cabeça (AC) em baias individuais automatizadas para o estudo do comportamento. A antinocicepção foi avaliada utilizando uma lâmpada de irradiação de calor registrando-se a latência para o reflexo de retirada do membro (LRRM) e a latência para o reflexo do frêmito cutâneo (LRFC), em delineamento experimental em blocos ao acaso com 10 repetições. O efeito sedativo sobre a ALE foi de aparecimento mais rápido no grupo exposto à xilazina, ao passo que a ptose da cabeça foi mais prolongada no grupo que recebeu romifidina. A romifidina promoveu aumento da LRRM e LRFC e a xilazina não causou efeito antinociceptivo medido pela LRFC. O efeito antinociceptivo da romifidina foi mais pronunciado que o da xilazina.

Palavras-chave: eqüino romifidina, xilazina, antinocicepção, sedação

\section{INTRODUCTION}

Romifidine and xylazine are agents classified as $\alpha_{2}$ adrenergic agonists. Xylazine is used in various animal species, and its sedative and antinociceptive effects have been explored in horses. The use of romifidine is attributed only to its sedative effect. These agents produce a dose- dependent sedative effect, evidenced by muscle relaxation, ataxia, palpebral, labial and head ptosis, cardiorespiratory depression, absence or reduction of reaction to external stimuli, diminution of locomotor activity and hypnosis, which occur a few minutes after administration (Kerr et al., 1972; Luna et al., 1996).

Recebido em 30 de agosto de 2004

Aceito em 14 de fevereiro de 2006

* Corresponding author (autor para correspondencia)

E-mail: aqueiroz@fcav.unesp.br 
The sedative and antinociceptive actions of $\alpha_{2}$ agonists are a result of its interaction with central pre-synaptic $\alpha_{2}$ adrenoceptors. These are known as auto-receptors, and when stimulated, they suppress the release of the chemical mediator at nerve endings (Aghajanian and Vandermaelen, 1982). Currently, it is known that the sedative and analgesic effects of these drugs are mediated by a reduction in adrenergic activity in the locus coeruleus and supra-spinal regions, respectively (Pertovaara et al, 1994).

Studies have been reported that xylazine is capable of inducing a block of superficial, profound and visceral pain (Pippi et al., 1979; Skarda et al., 1996). However, studies regarding the antinociceptive effect of romifidine are scarce. Hamm et al. (1995) studied the sedative and antinociceptive effects of detomidine and of romifidine in horses and concluded that the two agents cause sedation, but that only detomidine has analgesic properties. Therefore, further studies are needed to clarify whether or not romifidine possesses antinociceptive effects, since it shows a greater selectivity for the $\alpha_{2}$ receptor than does xylazine (Slater, 1993).

The recognition, characterization and control of pain are central concerns in daily clinical practice and $\alpha_{2}$ agonists play a sedative role. However, their routine use in horses for the purpose of preventing or alleviating pain should be preceded by studies determining and comparing their safety, efficacy and utility in this animal species.

Tobin et al. (1981) proposed a method for the determination of sedation in the equine species. In this method, the animal was placed in a totally enclosed stall, separated from external influences, and it was then observed through a glass window. The number of times that the animal lifts its left front leg was recorded as a quantification of its locomotor activity. Kamerling et al. (1988) automated this assessment of locomotor activity by placing photoelectric cells in the experimental stall, quantifying thus the locomotor activity of the animal.

The characterization of analgesia in animals is performed by means of measurements of reflexive and behavioral responses to painful stimulation. Hardy et al. (1940) described a method to measure the pain threshold by means of a painful stimulation caused by heat from a beam of concentrated light.

The purpose of this study was to compare the effects of therapeutic doses of romifidine and xylazine on nociception and sedation of horses.

\section{MATERIAL AND METHODS}

The experimental protocol was approved by the Institutional Animal Care and Use Committee at the FCAV-UNESP. The study was carried out on 10 Thoroughbred (TB) 8 to 13 year-old mares weighing between 454 and $552 \mathrm{~kg}$. The animals were submitted to a complete regimen of vaccination, deworming every four months with ivermectin and periodic grooming.

Sedation was evaluated by quantifying spontaneous locomotor activity (SLA) and head height $(\mathrm{HH})$ in two automated individual behavior stalls, measuring $4 \times 4 \mathrm{~m}$ equipped, each one, with four pairs of photoelectric sensors ${ }^{1}$ which were installed at $45 \mathrm{~cm}$ from the floor, juxtapositioned so as to form lines similar to those outlined in a tic-tac toe. Each interruption of infrared light generated a pulse, which was stored as counts per minute in a data storage unit $^{2}$ connected to a computer, quantifying SLA. The HH was measured based on the height in centimeters from the chin of the animal to the ground by means of rulers painted on the walls of the stalls.

The control of all the instrumentation, the observation of the animals, and $\mathrm{HH}$ measurements as well, were made possible from a room located between the two stalls, equipped with one-way windows so that the horses would not be aware of the observers.

The animals were confined to the stalls for an adaptative period of 14 hours before the start of the experimental procedures. At $7 \mathrm{AM}$ on the following day, hay and diet were given. At 8AM the remaining feed was removed and the sensors were connected to determine basal levels for

\footnotetext{
${ }^{1}$ SM31E and SM2A31R, Banner Engineering, Minneapolis, MN, USA.

${ }^{2}$ Campbell Scientific, CR10, Inc., Logan, UT, USA.
} 
SLA over 50 minutes. After this period, saline (control), $0.1 \mathrm{mg} / \mathrm{kg}$ romifidine ${ }^{1}$ or $1.0 \mathrm{mg} / \mathrm{kg}$ xylazine $^{2}$ were administered intravenously (IV) and the animals remained under observation for an uninterrupted period of six hours. Measurements for SLA and HH were taken at $15 \mathrm{~min}$ and immediately before IV injection of saline, romifidine or xylazine and at $5,10,15$, $30,45,60,90,120,150,180,240$ and 300 minutes after the injections.

Nociception was evaluated with a heat projection lamp adapted to the description of Kamerling et al. (1985) and built by the Electrical Engineering Department of the University of Kentucky, USA.

The painful stimulus was directed to the region of the proximal phalanx of the thoracic limb to measure the latency to the hoof withdrawal reflex (HWRL) and to the region of the withers of the horse to measure the latency to the skin twitch reflex (STRL). The skin of the regions to be exposed to the light was trichotomized and covered with a black water-based ink, to even out the reflection of light and consequently to make heat absorption uniform. The latencys were defined as the time between focusing of the light bean and limb withdrawal or skin twitch respectively. An ordinary lamp placed next to the heat lamp was activated periodically to reduce the possibility of the animals being conditioned by the presence of light. In both experiments, the cut-off time of exposure to the painful stimulus was 10 s to prevent tissue injury.
HWRL and STRL were always measured by the same observer at $-10 \mathrm{~min}$ and immediately before IV injection of saline, romifidine or xylazine and at 5, 10, 15, 30, 45, 60, 90, 120, 150,180 and 240 minutes after administrations. The order of drug administration was randomized and the observer was not blinded to treatment.

The total number of experiments performed was 30 for the evaluation of sedation and 30 for antinociception. All horses served as their own controls, and at least seven days elapsed before a horse was used in another experiment.

The statistical analysis was performed with the aid of the computational program (User's..., 1996) and the means of treatments (saline, romifidine and xylazine) at the time intervals examined were compared by Tukey test $(\mathrm{P}<0.05)$.

${ }^{1}$ Sedivet - Boehringer Ingelheim do Brasil Quím. e Farm. LTDA. SP, Brazil.

${ }^{4}$ Rompun - Bayer S.A. SP, Brazil.

\section{RESULTS AND DISCUSSION}

Table 1 shows a summary of the analysis of variance for SLA, HH, HWRL and STRL traits in Thoroughbred mares. The coefficient of variation for SLA was high (87.8\%), suggesting a wide individual variability in the measurement of spontaneous locomotor activity in horses.

Table 1. Summary of analysis of variance of spontaneous locomotor activity, head height, hoof withdrawal reflex latency and skin twitch reflex latency in Throughbred mares

\begin{tabular}{l|cccccccc}
\hline \multirow{2}{*}{$\begin{array}{c}\text { Source of } \\
\text { variation }\end{array}$} & \multicolumn{2}{c}{ Locomotor activity } & \multicolumn{2}{c}{ Head height } & Hoof withdrawal & \multicolumn{2}{c}{ Skin twitch reflex } \\
\cline { 2 - 9 } & DF & MS & DF & MS & DF & MS & DF & MS \\
\hline TR & 2 & $5151.47^{*}$ & 2 & $27336.60^{*}$ & 2 & 21.24 & 2 & $108.33^{*}$ \\
Within-animal & 18 & $36071.98^{*}$ & 18 & $301.55^{*}$ & 18 & $9.34^{*}$ & 18 & $14.86^{*}$ \\
TR & & & & & & & & \\
T & 15 & $7398.91^{*}$ & 15 & $13231.61 *$ & 15 & $2.44^{*}$ & 15 & $20.92^{*}$ \\
TR x T & 30 & $3513.30^{*}$ & 30 & $4198.22^{*}$ & 30 & $2.09^{*}$ & 30 & $11.50^{*}$ \\
Residue & 315 & 2339.21 & 188 & 145.43 & 188 & 0.65 & 188 & 3.47 \\
Total & 380 & & 253 & & 333 & & 335 & \\
CV & $87.76 \%$ & & $46.07 \%$ & & $33.13 \%$ & $50.29 \%$ & \\
$\mathrm{R}^{2}$ & $54.48 \%$ & & $91.81 \%$ & & $62.34 \%$ & $48.98 \%$ & \\
\hline
\end{tabular}

$\mathrm{TR}=$ treatment, $\mathrm{T}=$ time, $\mathrm{CV}=$ coefficient of variation, $\mathrm{DF}=$ degree of freedom, $\mathrm{R}^{2}=$ coefficient of determination. *significant $\mathrm{P}<0.0001$.

${ }^{1}$ Sedivet - Boehringer Ingelheim do Brasil Quím. e Farm. LTDA. SP, Brazil

${ }^{2}$ Rompun - Bayer S.A. SP, Brazil. 
The statistical model explained only $54.5 \%$ of the variation in SLA and $49.0 \%$ in STRL. The $\mathrm{R}^{2}$ for $\mathrm{HH}(91.8 \%)$ and HWRL $(62.3 \%)$ were relatively high. The coefficient of variation for HH, RWRL and STRL were relatively low, specially for hoof withdrawal $(33.1 \%)$ and head height $(46.1 \%)$. Table 1 also shows that all sources of variation significantly affected $(\mathrm{P}<0.0001)$ spontaneous locomotor activity, height of head, hoof withdrawal reflex ant skin twitch reflex. The interactions between each substance and time were significant, suggesting that the main effects (substances and time) should not be analyzed separately. Thus, it was carried out further statistical analyses to discriminate between the joint effect of substance and time.

Table 2 shows the sedative effects of romifidine and xylazine, measured as the diminution of the spontaneous locomotor activity of mares after the administration of the drugs, obtained as mean of the number of interruptions of the infrared beam sensors per minute. Xylazine caused a faster effect than romifidine. Regarding the sedative effect of romifidine and xylazine based on HP, Table 3 evidences that romifidine caused a longer-lasting sedative effect (180 minutes), than the effect of xylazine that lasted for 60 minutes $(\mathrm{P}<0.05)$.

The antinociceptive effect of romifidine and xylazine, evaluated by the increase in HWRL is show in Table 4. After IV administration of romifidine or xylazine, a significant increase in HWRL was observed in comparison to the control group, injected with saline solution $(\mathrm{P}<0.05)$. Both xylazine and romifidine caused a significative antinociceptive effect imediately after the injection, however, this effect lasts longer for romifidine than for xylazine. Table 5 displays the comparison of the antinociceptive effects of romifidine and xylazine for STRL. Xylazine, a drug known also for its analgesic effect, did not have an antinociceptive effect as did romifidine $(\mathrm{P}<0.05)$.

Table 2. Spontaneous locomotor activity of Throughbred mares before and after the intravenous administration of saline solution, romifidine and xylazine obtained as mean \pm SEM of the values of the number of interruptions per minute of infrared beam sensors

\begin{tabular}{cccr}
$\begin{array}{c}\text { Time } \\
\text { (minutes) }\end{array}$ & $\begin{array}{c}\text { Saline } \\
\text { (control) }\end{array}$ & $\begin{array}{c}\text { Romifidine } \\
\left(01 . \mathrm{mg}^{-1}\right)\end{array}$ & $\begin{array}{c}\text { Xylazine } \\
\left(01 . \mathrm{mg}^{-1} \mathrm{~kg}^{-1}\right)\end{array}$ \\
\hline-15 & $7.53 \pm 1.68 \mathrm{a}$ & $7.75 \pm 1.43 \mathrm{a}$ & $11.30 \pm 1.34 \mathrm{a}$ \\
0 & $6.14 \pm 1.70 \mathrm{a}$ & $11.4 \pm 2.60 \mathrm{a}$ & $7.93 \pm 1.64 \mathrm{a}$ \\
5 & $17.00 \pm 2.97 \mathrm{a}$ & $12.5 \pm 3.44 \mathrm{ab}$ & $6.26 \pm 1.57 \mathrm{~b}$ \\
10 & $12.60 \pm 3.05$ & $3.98 \pm 1.42 \mathrm{~b}$ & $3.08 \pm 0.44 \mathrm{~b}$ \\
15 & $7.50 \pm 2.02 \mathrm{a}$ & $3.34 \pm 1.35 \mathrm{ab}$ & $1.22 \pm 0.52 \mathrm{~b}$ \\
20 & $7.72 \pm 3.10 \mathrm{a}$ & $3.74 \pm 3.32 \mathrm{a}$ & $2.82 \pm 1.41 \mathrm{a}$ \\
25 & $6.62 \pm 1.21 \mathrm{a}$ & $3.81 \pm 1.05 \mathrm{a}$ & $3.12 \pm 2.02 \mathrm{a}$ \\
30 & $6.31 \pm 1.36 \mathrm{a}$ & $3.13 \pm 1.11 \mathrm{a}$ & $4.61 \pm 1.70 \mathrm{a}$ \\
45 & $7.49 \pm 1.64 \mathrm{a}$ & $4.76 \pm 1.20 \mathrm{a}$ & $6.66 \pm 2.90^{\mathrm{a}}$ \\
60 & $5,61 \pm 1.10 \mathrm{a}$ & $5.07 \pm 0.97 \mathrm{a}$ & $11.10 \pm 6.02 \mathrm{a}$ \\
75 & $9.63 \pm 2.45 \mathrm{a}$ & $5.67 \pm 0.83 \mathrm{a}$ & $13.80 \pm 5.94 \mathrm{a}$ \\
90 & $9.94 \pm 1.45 \mathrm{a}$ & $4.52 \pm 0.86 \mathrm{a}$ & $12.30 \pm 5.94 \mathrm{a}$ \\
120 & $11.30 \pm 2.03 \mathrm{a}$ & $6.45 \pm 1.45 \mathrm{a}$ & $13.10 \pm 5.19 \mathrm{a}$ \\
150 & $12.10 \pm 2.59 \mathrm{a}$ & $6.95 \pm 1.32 \mathrm{a}$ & $15.50 \pm 5.50 \mathrm{a}$ \\
180 & $13.70 \pm 2.48 \mathrm{a}$ & $6.91 \pm 1.19 \mathrm{a}$ & $11.40 \pm 2.59 \mathrm{a}$ \\
210 & $11.50 \pm 2.27 \mathrm{a}$ & $7.17 \pm 1.36 \mathrm{a}$ & $11.60 \pm 2.31 \mathrm{a}$ \\
240 & $10.90 \pm 2.82 \mathrm{a}$ & $6.24 \pm 1.34 \mathrm{a}$ & $8.88 \pm 1.96 \mathrm{a}$ \\
270 & $11.30 \pm 2.36 \mathrm{a}$ & $6.41 \pm 1.47 \mathrm{a}$ & $11.00 \pm 2.64 \mathrm{a}$ \\
300 & $11.80 \pm 2.30 \mathrm{a}$ & $4.92 \pm 1.23 \mathrm{a}$ & $11.80 \pm 2.99 \mathrm{a}$ \\
\hline
\end{tabular}

The values are expressed as means \pm SEM. SEM $=$ standard error mean.

Means within a row with no common letters differ $(\mathrm{P}<0.05)$ by Tukey test. 


\section{Christovão et al.}

Table 3. Mean \pm SEM of the head height the Throughbred mares before and after the intravenous administration of saline solution (control), romifidine and xylazine

\begin{tabular}{cccc}
$\begin{array}{c}\text { Time } \\
(\text { minutes })\end{array}$ & $\begin{array}{c}\text { Saline } \\
(\text { control })\end{array}$ & $\begin{array}{c}\text { Romifidine } \\
\left(01 . \mathrm{mg}^{-1}\right)\end{array}$ & $\begin{array}{c}\text { Xylazine } \\
\left(01 . \mathrm{mg}^{-1} \mathrm{~kg}^{-1}\right)\end{array}$ \\
\hline-15 & $86.65 \pm 6.33 \mathrm{a}$ & $88.34 \pm 2.11 \mathrm{a}$ & $70.94 \pm 3.54 \mathrm{a}$ \\
0 & $89.67 \pm 4.88 \mathrm{a}$ & $80.43 \pm 2.09 \mathrm{a}$ & $85.44 \pm 3.95 \mathrm{a}$ \\
5 & $86.55 \pm 3.90 \mathrm{a}$ & $78.33 \pm 1.98 \mathrm{a}$ & $80.65 \pm 2.69 \mathrm{a}$ \\
10 & $88.41 \pm 3.76 \mathrm{a}$ & $27.54 \pm 2.99 \mathrm{~b}$ & $12.77 \pm 2.02 \mathrm{~b}$ \\
15 & $85.77 \pm 4.20 \mathrm{a}$ & $29.99 \pm 3.40 \mathrm{~b}$ & $11.91 \pm 1.87 \mathrm{~b}$ \\
20 & $90.08 \pm 3.66 \mathrm{a}$ & $31.46 \pm 2.11 \mathrm{~b}$ & $10.98 \pm 2.83 \mathrm{~b}$ \\
25 & $86.54 \pm 3.98 \mathrm{a}$ & $26.99 \pm 3.88 \mathrm{~b}$ & $17.54 \pm 1.76 \mathrm{~b}$ \\
30 & $87.45 \pm 4.01 \mathrm{a}$ & $28.41 \pm 4.91 \mathrm{~b}$ & $29.78 \pm 2.65 \mathrm{~b}$ \\
45 & $84.77 \pm 3.32 \mathrm{a}$ & $30.50 \pm 2.78 \mathrm{~b}$ & $54.86 \pm 3.95 \mathrm{~b}$ \\
60 & $88.40 \pm 3.56 \mathrm{a}$ & $66.90 \pm 1.96 \mathrm{~b}$ & $35.64 \pm 3.76 \mathrm{~b}$ \\
75 & $86.77 \pm 4.22 \mathrm{a}$ & $57.90 \pm 1.97 \mathrm{~b}$ & $66.88 \pm 4.64 \mathrm{a}$ \\
90 & $91.33 \pm 3.88 \mathrm{a}$ & $51.90 \pm 2.66 \mathrm{~b}$ & $85.41 \pm 3.87 \mathrm{a}$ \\
120 & $88.40 \pm 6.08 \mathrm{a}$ & $34.00 \pm 3.87 \mathrm{~b}$ & $78.99 \pm 3.89 \mathrm{a}$ \\
150 & $85.66 \pm 5.49 \mathrm{a}$ & $55.88 \pm 3.51 \mathrm{~b}$ & $80.93 \pm 4.31 \mathrm{a}$ \\
180 & $80.45 \pm 4.03 \mathrm{a}$ & $65.90 \pm 2.99 \mathrm{~b}$ & $77.90 \pm 3.76 \mathrm{a}$ \\
210 & $79.77 \pm 3.60 \mathrm{a}$ & $68.88 \pm 3.56 \mathrm{a}$ & $72.99 \pm 2.98 \mathrm{a}$ \\
240 & $95.01 \pm 3.65 \mathrm{a}$ & $78.29 \pm 4.16 \mathrm{a}$ & $86.60 \pm 4.66 \mathrm{a}$ \\
270 & $84.31 \pm 3.88 \mathrm{a}$ & $80.90 \pm 4.02 \mathrm{a}$ & $84.94 \pm 3.54 \mathrm{a}$ \\
300 & $86.66 \pm 3.94 \mathrm{a}$ & $85.41 \pm 3.22 \mathrm{a}$ & $83.20 \pm 2.45 \mathrm{a}$ \\
\hline
\end{tabular}

The values are expressed as means \pm SEM. SEM=standard error mean.

Means within a row with no common letters differ $(\mathrm{P}<0.05)$ by Tukey test.

Table 4. Mean \pm SEM of the latency for the hoof withdrawal reflex the Throughbred mares, before and after the intravenous administration of saline solution, romifidine and xylazine

\begin{tabular}{cccc}
\hline \multirow{2}{*}{$\begin{array}{c}\text { Time } \\
\text { (minutes) }\end{array}$} & \multicolumn{3}{c}{ Treatment } \\
\cline { 2 - 4 } & $\begin{array}{c}\text { Saline } \\
\text { (control) }\end{array}$ & $\begin{array}{c}\text { Romifidine } \\
\left(01 . \mathrm{mg}^{-1} \mathrm{~kg}^{-1}\right)\end{array}$ & $\begin{array}{c}\text { Xylazine } \\
\left(01 . \mathrm{mg}^{-1} \mathrm{~kg}^{-1}\right)\end{array}$ \\
\hline-10 & $2.69 \pm 0.23 \mathrm{a}$ & $2.86 \pm 0.18 \mathrm{a}$ & $2.79 \pm 0.27 \mathrm{a}$ \\
0 & $2.79 \pm 0.17 \mathrm{a}$ & $2.85 \pm 0.14 \mathrm{a}$ & $3.15 \pm 0.25 \mathrm{a}$ \\
5 & $2.57 \pm 0.12 \mathrm{a}$ & $5.31 \pm 0.69 \mathrm{~b}$ & $6.54 \pm 1.07 \mathrm{~b}$ \\
10 & $2.46 \pm 0.17 \mathrm{a}$ & $6.64 \pm 0.92 \mathrm{~b}$ & $7.15 \pm 1.16 \mathrm{~b}$ \\
15 & $2.69 \pm 0.13 \mathrm{a}$ & $7.95 \pm 0.85 \mathrm{~b}$ & $6.90 \pm 1.26 \mathrm{~b}$ \\
30 & $2.56 \pm 0.22 \mathrm{a}$ & $5.64 \pm 0.77 \mathrm{~b}$ & $4.27 \pm 0.39 \mathrm{ab}$ \\
45 & $2.67 \pm 0.13 \mathrm{a}$ & $5.72 \pm 0.97 \mathrm{~b}$ & $3.22 \pm 0.45 \mathrm{a}$ \\
60 & $2.63 \pm 0.20 \mathrm{a}$ & $4.73 \pm 0.49 \mathrm{~b}$ & $2.95 \pm 0.36 \mathrm{a}$ \\
90 & $2.60 \pm 0.25 \mathrm{a}$ & $4.65 \pm 0.60 \mathrm{~b}$ & $3.22 \pm 0.42 \mathrm{ab}$ \\
120 & $2.66 \pm 0.16 \mathrm{a}$ & $3.94 \pm 0.51 \mathrm{~b}$ & $3.15 \pm 0.18 \mathrm{ab}$ \\
150 & $2.69 \pm 0.13 \mathrm{a}$ & $3.65 \pm 0.35 \mathrm{~b}$ & $2.77 \pm 0.10 \mathrm{ab}$ \\
180 & $2.52 \pm 0.11 \mathrm{a}$ & $3.28 \pm 0.21 \mathrm{~b}$ & $3.01 \pm 0.09 \mathrm{ab}$ \\
240 & $2.52 \pm 0.11 \mathrm{a}$ & $3.46 \pm 0.25 \mathrm{~b}$ & $2.86 \pm 0.07 \mathrm{ab}$ \\
300 & $2.61 \pm 0.11 \mathrm{a}$ & $3.32 \pm 0.10 \mathrm{~b}$ & $2.94 \pm 0.00 \mathrm{ab}$ \\
360 & $2.52 \pm 2.78 \mathrm{a}$ & $3.24 \pm 0.12 \mathrm{a}$ & $2.88 \pm 0.00 \mathrm{ab}$ \\
\hline
\end{tabular}

The values are expressed as means \pm SEM. SEM=standard error mean.

Means within a row with no common letters differ $(\mathrm{P}<0.05)$ by Tukey test. 
Sedative and antinociceptive effects...

Table 5. Mean \pm SEM of the latency for the skin twitch the Thoroughbred mares, before and after the intravenous administration of saline solution, romifidine and xylazine

\begin{tabular}{cccc}
$\begin{array}{c}\text { Time } \\
\text { (minutes) }\end{array}$ & $\begin{array}{c}\text { Saline } \\
\text { (control) }\end{array}$ & $\begin{array}{c}\text { Romifidine } \\
\left(01 . \mathrm{mg}^{-1} \mathrm{~kg}^{-1}\right)\end{array}$ & $\begin{array}{c}\text { Xylazine } \\
\left.\left(01 . \mathrm{mg}_{\mathrm{kg}}\right)^{-1}\right)\end{array}$ \\
\hline-10 & $2.21 \pm 0.23 \mathrm{a}$ & $2.42 \pm 0.27 \mathrm{a}$ & $2.34 \pm 0.18 \mathrm{a}$ \\
0 & $2.05 \pm 0.21 \mathrm{a}$ & $2.29 \pm 0.27 \mathrm{a}$ & $1.82 \pm 0.26 \mathrm{a}$ \\
5 & $2.14 \pm 0.22 \mathrm{a}$ & $3.18 \pm 0.42 \mathrm{a}$ & $2.75 \pm 0.28 \mathrm{a}$ \\
10 & $2.22 \pm 0.25 \mathrm{a}$ & $3.40 \pm 1.27 \mathrm{a}$ & $2.05 \pm 0.31 \mathrm{a}$ \\
15 & $2.03 \pm 0.19 \mathrm{a}$ & $4.87 \pm 1.13 \mathrm{~b}$ & $1.99 \pm 0.38 \mathrm{ab}$ \\
30 & $2.13 \pm 0.24 \mathrm{a}$ & $4.73 \pm 1.11 \mathrm{a}$ & $1.56 \pm 0.25 \mathrm{a}$ \\
45 & $2.08 \pm 0.23 \mathrm{a}$ & $3.68 \pm 1.76 \mathrm{a}$ & $1.62 \pm 0.23 \mathrm{a}$ \\
60 & $2.15 \pm 0.19 \mathrm{a}$ & $2.73 \pm 0.20 \mathrm{a}$ & $2.15 \pm 0.26 \mathrm{a}$ \\
90 & $2.02 \pm 0.22 \mathrm{a}$ & $2.61 \pm 0.41 \mathrm{a}$ & $2.12 \pm 0.18 \mathrm{a}$ \\
120 & $2.16 \pm 0.21 \mathrm{a}$ & $2.42 \pm 0.36 \mathrm{a}$ & $2.10 \pm 0.24 \mathrm{a}$ \\
150 & $2.13 \pm 0.20 \mathrm{a}$ & $2.25 \pm 0.23 \mathrm{a}$ & $1.95 \pm 0.19 \mathrm{a}$ \\
180 & $2.17 \pm 0.20 \mathrm{a}$ & $2.13 \pm 0.13 \mathrm{a}$ & $1.90 \pm 0.22 \mathrm{a}$ \\
240 & $2.15 \pm 0.19 \mathrm{a}$ & $2.23 \pm 0.13 \mathrm{a}$ & $2.08 \pm 0.17 \mathrm{a}$ \\
300 & $2.15 \pm 0.20 \mathrm{a}$ & $2.12 \pm 0.13 \mathrm{a}$ & $2.31 \pm 0.15 \mathrm{a}$ \\
360 & $2.06 \pm 0.21 \mathrm{a}$ & $2.14 \pm 0.14 \mathrm{a}$ & $1.97 \pm 0.17 \mathrm{a}$ \\
\hline
\end{tabular}

The values are expressed as means \pm SEM. SEM=standard error mean.

Means within a row with no common letters differ $(\mathrm{P}<0.05)$ by Tukey test.

$\mathrm{Alpha}_{2}$ agonist agents are very well known and are used in horses to facilitate clinical and laboratory examinations and improving therapeutic procedures, as well as for preanesthetic procedures (McCashin et al., 1975). In veterinary practice, as well as in experimental studies, the xylazine is used in situations that require sedation and/or analgesia. The same is not true for romifidine, which is used mainly for its sedative property and not for its antinociceptive effect.

As sedative effect of romifidine and xylazine on SLA were examined (Table 2), the expected result was not obtained. There was a wide variation in the activities of individual horses $(\mathrm{CV}=87.8 \%)$ and the statistical model explained only about half of the variation in this trait. Although the behaviour chambers were insulated and white noise was present, the horses might not be completely isolated from outside stimuli. In addition, the animals used in the experiment had a calm temperament, what may not be the ideal since horses with this behaviour do not demonstrate significant decrease in SLA when exposed to central depressive agents. Despite this, Table 2 shows that the xylazine treated group showed a more rapid onset, while the romifidine treated group showed a longer period of sedation as measure by the $\mathrm{HH}$ (Table 3). These data are in agreement with Voegtli (1988) and England et al. (1992). These autors concluded that the advantages of romifidine over other $\alpha_{2}$ adrenergic agonists, such as xylazine and detomidine, are of longer sedative effect and lower incidence of ataxia.

Although xylazine is known for its analgesic action, in the present study, the antinociceptive effect of romifidine was better than the xylazine, suggesting the need of further studies of these drugs in the equine species.

\section{REFERENCES}

AGHAJANIAN, G.K.; VANDERMAELEN, C.P Alpha $_{2}$-adrenoceptor mediated hyperpolarisation of locus coeruleus neurons: intracellular studies in vivo. Science, v.215, p.1394-1396, 1982.

ENGLAND, G.C.W.; CLARKE, K.W.; GOOSSENS, L. A comparison of the sedative effects of three alpha 2-adrenoceptor agonists in the horse. J. Vet. Pharmacol. Therap., v.15, p.194-201, 1992.

HAMM, D.; TURCHI, P.; JÖCHLE, W. Sedative and analgesic effects of detomidine and romifidine in horses. Vet. Rec., v.13, p.324-327, 1995.

HARDY, J.D.; WOLFF, H.G.; GOODELL, H. Studies on pain: a new method for measuring pain threshold, observations on spatial 
summations of pain. J. Clin. Invest., v.19, p.649657, 1940.

KAMERLING, S.G.; WECKMAN, T.J.; DEQUICK, D.J. et al. A method for studying cutaneous pain perseption and analgesia in horse. J. Pharmacol. Methods, v.13, p.267-274, 1985.

KERR, D.D.; JONES, E.W.; HUGGINS, K. et al. Sedative and other effects of xylazine given intravenously to horses. Am. J. Vet. Res., v.33, p.525-532, 1972.

LUNA, S.P.L.; VIEIRA, F.A.F.; PAVANI, R.C. et al. Comparation entre detomidina e romifidine em equinos. Hora Vet., v.15, p.56-59, 1996.

MCCASHI, F.B.; GABEL, A.A. Evaluation of xylazine as a sedative and preanesthetic agent in horses. Am. J. Vet. Res., v.3, p.1421-1429, 1975.

PERTOVAARA，A.; HÄMÄLÄINEN，M.M.; KAUPPILA, T. et al. Dissociation of the $\alpha_{2}$ adrenergic antinociception from sedation following microinjection of medetomidine into the locus coeruleus in rats. Elsevier Sci., v.57, 207-215, 1994.
PIPPI, N.L.; LUMB, W.W. Objective tests of analgesic drugs in horses. Am. J. Vet. Res., v.40, p.1082-1082, 1979.

SKARDA, R.T.; MUIR, W.W. Comparação dos efeitos cardiovasculares, respiratórios, ptose da cabeça, antinociceptivos e posição dos membros pélvicos em éguas após administração de xilazina e detomidina. J. Vet. Res., v.57, p.133845, 1996.

SLATER, J. Performing reliable and safe sedation in horses. J. Pharmacol. Clin., v.2, p.12, 1993.

TOBIN, T. Drugs and the performance horse. Springfield: Charles C. Thomas, 1981.p.463.

USER'S guide: statistical analysis system. Version 6.03. Cary, NC: SAS Institute, 1996. 530 p.

VOEGTLI, K. Studies on the sedative and analgesic effect of an $\alpha_{2}$-adrenoceptor agonist (STH 2130, Boehringer) in horses. 1988. Dissertation. Faculty of Veterinary Medicine, University of Berne, Switzerland. 